\title{
Emotional Spiritual Quotient (ESQ) dalam Pembelajaran Pendidikan Agama Islam Kurikulum 2013
}

\author{
Moh. Sulaiman \\ Institut Agama Islam Darussalam (IAID) Ciamis \\ Email: moh.sulaimansdrj@gmail.com \\ M. Djaswidi Al Hamdani \\ Program Pascasarjana, Institut Agama Islam Darussalam (IAID) Ciamis, Jawa Barat \\ Email: dr.djaswidi@yahoo.com \\ Abdul Azis \\ Program Pascasarjana, Institut Agama Islam Darussalam (IAID) Ciamis, Jawa Barat \\ Email: abdul.azisiaid@gmail.com
}

Received: September 6, 2017 | Accepted: February 8, 2018

\begin{abstract}
This article aims to explore aspects of the emotional spiritual quotient (ESQ) in curriculum 2013 of Islamic education and its relevance to contemporary Islamic education. With a qualitative approach, this article found that aspects of emotional spiritual quotient (ESQ) in curriculum 2013 of Islamic Education include; faith and piety, noble character, honesty, discipline, responsibility, care (mutual cooperation, cooperation, tolerance, peace), polite, responsive and pro-active confident in interacting with family, friends, teachers, environment and society. The relevance of these findings to the current phenomenon of Islamic education can be concluded that in the world of education today requires a learning system that prioritizes a balance between intellectual, emotional and spiritual intelligence.
\end{abstract}

\begin{abstract}
Abstrak
Artikel ini bertujuan untuk mencari aspek-aspek emotional spiritual quotient (ESQ) dalam pembelajaran PAI kurikulum 2013 dan relevansinya terhadap pendidikan Islam masa kini. Dengan pendekatan kualitatif, artikel ini menemukan bahwa aspek-aspek emotional spiritual quotient (ESQ) dalam pembelajaran Pendidikan Agama Islam Kurikulum 2013 meliputi keimanan dan ketakwaan, akhlak mulia, jujur, disiplin, tanggungjawab, peduli (gotong royong, kerjasama, toleran, damai), santun, responsif dan pro-aktif percaya diri dalam berinteraksi dengan keluarga, teman, guru, lingkungan dan masyarakat. Adapun relevansi hasil temuan ini dengan fenomena pendidikan saat ini dapat disimpulkan bahwa dalam dunia pendidikan masa kini memerlukan sistem pembelajaran yang lebih memprioritaskan keseimbangan antara kecerdasan intelektual, emosional dan spiritual.
\end{abstract}




\section{Keywords}

Emotional Spiritual Quotient (ESQ), Islamic religious curriculum

\section{Pendahuluan}

Pendidikan, dalam arti umum mencakup segala usaha dan perbuatan dari generasi tua untuk mengalihkan pengalamannya, pengetahuannya, kecakapannya serta keterampilannya kepada generasi muda untuk memungkinnya melakukan fungsi hidupnya dalam pergaulan bersama, dengan sebaik-baiknya (Ali, 1993, p. 8).

Pendidikan dalam Islam, antara lain berusaha untuk mengembangkan alat-alat potensial dari manusia tersebut seoptimal mungkin untuk dapat difungsikan sebagai sarana bagi pemecahan masalah-masalah hidup dan kehidupan, pengembangan ilmu pengetahuan dan teknologi serta budaya manusia, dan pengembangan sikap iman dan takwa kepada Allah Swt (Muhaemin, 2004, p. 16).

Pengertian pendidikan bahkan lebih diperluas cakupannya sebagai aktivitas dan fenomena. Pendidikan sebagai aktivitas berarti upaya yang secara sadar dirancang untuk membantu seseorang atau sekelompok orang dalam mengembangkan pandangan hidup (bagaimana orang akan menjalani dan memanfaatkan hidup dalam kehidupannya), sikap hidup, dan keterampilan hidup, baik yang bersifat manual (petunjuk praktis) maupun mental dan sosial. Sedangkan pendidikan sebagai fenomena adalah peristiwa perjumpaan antara dua orang atau lebih yang dampaknya ialah berkembangnya suatu pandangan hidup, sikap hidup atau keterampilan hidup pada salah satu atau beberapa pihak (Muhaemin, 2004, p. 37).

Jadi pendidikan merupakan suatu proses yang dilakukan oleh masyarakat dalam rangka untuk mempersiapkan generasi seterusnya agar dapat bersosialisasi dan beradaptasi serta memecahkan berbagai persoalan dalam kehidupan sosial mereka, karena pendidikan merupakan bagian dari strategi dalam kehidupan. Proses penyesuaian manusia terhadap masyarakat dan lingkungannya, dengan semua ruang lingkup yang terdapat di dalamnya. Namun demikian proses tersebut bukan merupakan suatu hal yang sangat mudah, mengingat akan kemampuan yang terbatas pada diri manusia itu sendiri.

Perkembangan pendidikan yang memunculkan fenomena universal, unsur orientasi yang mutlak terhadap kebutuhan manusia secara duniawi ataupun religius menuntut adanya pemilahan atau verifikasi terhadap 
pendidikan dengan konsep yang jelas. Tujuan pendidikan adalah untuk membangkitkan dan meneguhkan kembali cara-cara lama yang lebih baik, untuk memapankan kembali tolok ukur keyakinan dan perilaku tradisional (O`neil, 2002, p. 249).

Pendidikan menghendaki berbagai macam teori dan pemikiran dari para ahli pendidik dan ahli filsafat, guna melancarkan jalan dan memudahkan caracara bagi para guru dan pendidik dalam menyampaikan ilmu pengetahuan dan pengajaran kepada para siswa dan anak didik. Ahli filsafat pendidikan berusaha mencari fomula tunggal yang dengan formula itu semua aktivitas belajar manusia dapat dimengerti dan diatur (Ali, 1993, p. 37).

Pendidikan sebagai usaha memanusiakan manusia dalam arti bersifat manusiawi senantiasa perlu diorientasikan komponen-komponennya, sehingga tetap bermakna dan relevan dengan kebutuhan zaman, sosial masyarakat serta alam semesta. Dalam Islam konsep pendidikan bukan hanya dikenal dengan konsep tarbiyah dan ta'lim, tetapi juga $t a^{\prime} d i b$ yang meliputi pembinaan potensi intelektualitas, emosinalitas, dan spiritualitas (Al-Attas, 1984, p. 58).

Pemaknaan pendidikan lebih jauh juga didefinisikan sebagai usaha untuk menginternalisasikan nama-nama keagungan Tuhan. Intensitas pengajaran Tuhan kepada Adam yang menyebabkannya harus dipatuhi dan dimuliakan adalah karena telah memiliki tiga macam kecerdasan yakni: kecerdasan intelektual, emosional dan spiritual. Dengan kecerdasan intelektual, Adam membaca, memahami, memanfaatkan dan memakmurkan alam semesta. Dengan emosional, Adam memiliki sikap empati, kasih sayang dan menghargai ketentuan Allah. Dengan kecerdasan spiritual Adam mampu patuh, taat dan berusaha menghambakan diri kepada Allah Swt (Budiman, 2016, p. ii).

Untuk mencapai tujuan Pendidikan Islam seperti di atas, sebagai permasalahan pokok yang perlu diperhatikan adalah pokok konsep pendidikan itu sendiri. Aspek pendidikan itu berorientasi pada nilai-nilai ke-Tuhanan, pada nilai-nilai kemanusiaan, dan berorientasi pada nilai-nilai kealaman, sehingga melahirkan manusia-manusia yang cinta akan pelestarian alam ( $h a b l$ min al-Alam).

Seiring dengan menjamurnya teori-teori pendidikan, semakin tidak terjadi proses interaksi nilai pendidikan sebagai usaha memanusiakan manusia. Dalam kata lain, menyadarkan subyek didik sehingga berfikir kreatif, berperasaan manusiawi, dan berkecerdasan Ilahi. Ketidak keberhasilan cita dan ide pendidikan ini ditandai dengan membudayanya fenomena tidak manusiawi, seperti menggejalanya budaya narkoba, aksi tawuran, dan demonstrasi sebagai alternatif penyaluran aspirasi subyek didik dan masyarakat pada umumnya. 
Sistem dari pendidikan modern sekarang, belum mampu memberikan kesejahteraan hidup manusia, keluhuran moral, kemajuan politik, ekonomi, ilmu pengetahuan dan keharmonisan sosial budaya. Pendidikan modern tidak lebih dari menambah daftar manusia yang tidak mampu mengerjakan apa yang sudah terlanjur diketahui, artinya mereka mendapat gelar "pengangguran intelektual", yang memunculkan kejahatan intelektual terus membengkak laksana kanker ganas. Sistem pendidikan yang mampu mengkonstruksi pribadi yang intelektualis, moralis, dan spiritualis. Keterpaduan antara potensi intelektual, moral dan spiritual, akan melahirkan beragam kecerdasan, seperti kecerdasan transcendental atau kecerdasan spiritual plus (Tasmara, 2001, p. xii).

Ary Ginanjar Agustian dalam (Tasmara, 2001, p. xi) melahirkan sebuah istilah yang segar berupa pemahaman dan pendalaman kedua inti rukun Iman dan rukun Islam. Ia memberi nama ESQ (emosional and spiritual quotient), atau kecerdasan emosi dan spiritual. Kecerdasan spiritual, yakni suatu kecerdasan yang bukan hanya tertumpu pada kualitas manusiawi (kognitif, afektif, dan psikomotor) seperti halnya yang diterjemahkan oleh psikolog barat, Benyamin Bloom, tetapi juga tertumpu pada pada nilai-nilai ke-Tuhanan (transenden). Kecerdasan seperti ini akan menjadikan kekuatan moralitas yang berpihak dan hanya akan terus berpihak secara konsisten pada nilai-nilai ke universalan. Kecerdasan spiritual merupakan fenomena baru yang lahir di abad XXI. Fenomena kehadiran aliran spiritual yang bermakna spirit atau semangat, lahir di era modern dan menyimbolkan dirinya sebagi new age, new thought, dan religion science.

Pemaknaan apa itu kecerdasan spiritual masih terdapat perbedaan pandangan di kalangan para pakar, di antaranya: Pertama, Ary Ginanjar Agustian, kecerdasan emosi dan spiritual bersumber dari suara hati. Sedangkan suara-suara hati itu ternyata berasal dan sama persis dengan nama-nama sifatsifat Ilahiyah yang telah terekam di dalam jiwa setiap manusia, seperti dorongan ingin mulia, dorongan ingin belajar, dorongan ingin bijaksana, dan dorongan-dorongan lainya (Agustian, 2007, p. 200). Kedua, Jalaludin Rakhmat dan Komaruddin Hidayat berpendapat sebaliknya, bahwa kecerdasan spiritual tidaklah sama dengan agama. Orang yang beragama belum tentu memiliki kecerdasan spiritual, karena agama di samping sebagai aturan-aturan formal, juga kadang-kadang berperan terhadap tragedI saling bunuh sesama manusia (Hidayat \& dkk., 2002, p. 21).

Dalam dunia pendidikan masa kini, yang lebih bercorak modern dan sekuler kadang-kadang berakibat ke arah hilangnya kualitas manusiawi (spiritual dan moral). Oleh karena itu perlu diterapkan suatu sistem pembelajaran yang lebih memprioritaskan keseimbangan antara kecerdasan 
intelektual, emosional dan spiritual. Proses Pembelajaran yang diarahkan kepada kualitas intelektual saja, belum tentu akan menghasilkan kecerdasan emosional dan spiritual. Sebaliknya proses pembelajaran yang diarahkan kepada kualitas emosional dan spiritual dengan sendirinya akan melahirkan kecerdasan intelektual, emosional dan spiritual sekaligus.

Danah Zohar dan Ian Marshall mengatakan bahwa SQ tidaklah sama dengan agama. Menurutnya, SQ beroperasi dari otak (realitas ilmiah), sementara agama (transendensitas) dari wahyu. Persoalanya apakah benar spiritual seseorang akan tumbuh dan berkembang dengan baik bila tidak didukung oleh agama, artinya tanpa bimbingan wahyu dan Tuhan. Salah satu prioritas pengembangan nasional di bidang pendidikan dalam rangka pengembanga kualitas sumber daya manusia adalah peningkatan mutu setiap jenis dan jenjang pendidikan (Zohar \& Marshall, 2007, p. 14).

Menurut Undang-undang Nomor 20 Tahun 2003 Pasal 1 Ayat (19) kurikulum adalah "seperangkat rencana dan pengaturan mengenai tujuan, isi, dan bahan pelajaran serta cara yang digunakan sebagai pedoman penyelenggaraan kegiatan pembelajaran untuk mencapai tujuan pendidikan tertentu”. Berdasarkan pengertian tersebut, ada dua dimensi kurikulum, yang pertama adalah rencana dan pengaturan mengenai tujuan, isi, dan bahan pelajaran. Sedangkan yang kedua adalah cara yang digunakan untuk kegiatan pembelajaran.

Pengembangan Kurikulum 2013 merupakan langkah lanjutan Pengembangan Kurikulum Berbasis Kompetensi yang telah dirintis pada tahun 2004 dan KTSP 2006 yang mencakup kompetensi sikap, pengetahuan, dan keterampilan secara terpadu. Kurikulum Madrasah 2013 bertujuan untuk mempersiapkan manusia Indonesia agar memiliki kemampuan hidup sebagai pribadi dan warga negara yang beriman, produktif, kreatif, inovatif, dan afektif serta mampu berkontribusi pada kehidupan bermasyarakat, berbangsa, bernegara, dan peradaban dunia.

Dunia pendidikan dewasa ini sering dikritik oleh masyarakat karena adanya sejumlah pelajar dan lulusan pendidikan yang menunjukkan sifat yang kurang terpuji di masyarakat. Banyak pelajar yang terlibat dalam tindak perilaku negatif. Perbuatan tidak terpuji yang dilakukan para pelajar tersebut benar-benar telah meresahkan masyarakat dan merepotkan aparat kepolisian. Hal tersebut masih ditambah lagi dengan adanya peningkatan jumlah pengangguran yang kebanyakan keluaran pendidikan.

Keadaan ini menjadikan gambaran pendidikan kita semakin tidak menarik dan tidak enak dipandang mata. Hal ini mengakibatkan semakin menurunkan kepercayaan masyarakat terhadap dunia pendidikan kita. Jika keadaan tersebut tidak segera dicarikan solusinya, maka akan ada kesulitan 
untuk mencari alternatif lain yang paling efektif untuk membina moralitas masyarakat. Oleh karena itu, upaya mencari solusi untuk memperbaiki dunia pendidikan dan mencari sebab-sebabnya merupakan hal yang tidak bisa ditunda lagi. Di antara berbagai faktor yang menjadikan pendidikan kurang mampu menghasilkan lulusan yang diharapkan adalah karena dunia pendidikan selama ini hanya membina kecerdasan intelektual, wawasan dan keterampilan, tanpa dibarengi dengan pembinaan kecerdasan emosional khususnya dan penanaman nilai sikap spiritual (Ali, 1993, p. 18).

Pendidikan Agama Islam sangat dibutuhkan bagi umat Islam, agar dapat memahami secara benar ajaran Islam sebagai agama yang sempurna. Kesempurnaan ajaran Islam yang dipelajari secara integral diharapkan dapat meningkatkan kualitas umat Islam dalam keseluruhan aspek kehidupanya. Agar ajaran Islam dapat dipelajari secara efektif dan efisien, maka perlu dikembangkan kurikulum pendidikan agama Islam sesuai dengan perkembangan dan tuntutan zaman.

Kemajuan ilmu pengetahuan memperkuat dampak globalisasi dan kemajuan teknologi. Perubahan yang terjadi akhir-akhir ini mengalahkan kecepatan dan dimensi perubahan yang terjadi dalam kehidupan manusia pada masa-masa sebelumnya. Perubahan tersebut telah tampak dalam kehidupan manusia dari tingkat global, nasional, dan regional serta dari kehidupan sebagai manusia, warga negara, anggota masyarakat. Perubahan dan penyempurnaan tersebut menjadi penting sejalan denganadanya kesinambungan segala kemungkinan yang terjadi berkaitan dengan perkembangan ilmu pengetahuan, teknologi, dan seni budaya pada tataran lokal, regional, nasional, dan global di masa yang akan datang.

Kenyataan adanya amanat legal dan kehidupan manusia yang berubah cepat yang menyebabkan perubahan dan penyempurnaan kurikulum Pendidikan Agama Islam merupakan suatu keniscayaan yang tak dapat dihindari. Atas dasar itu, rancangan konseptual dan kontekstual penyempurnaan kurikulum menjadi suatu keniscayaan yang harus disiapkan dan dilaksanakan.

Pengembangan kurikulum dilakukan karena adanya berbagai tantangan yang dihadapi, baik tantangan internal maupun tantangan eksternal. Di samping itu, dalam menghadapi tuntutan perkembangan zaman, perlu adanya penyempurnaan pola pikir dan penguatan tata kelola kurikulum serta pendalaman dan perluasan materi. Selain itu yang tidak kalah pentingnya adalah perlunya penguatan proses pembelajaran, penyesuaian beban belajar dan penilaian agar dapat menjamin kesesuaian antara apa yang diinginkan dengan apa yang dihasilkan. Dengan demikian, maka yang menjadi inti permasalahan dari penelitian ini adalah begaimana konsep Emotional Spiritual Quotient 
(ESQ) Dalam Proses Pembelajaran Pendidikan Agama Islam Kurikulum 2013. Sesuai dengan variabel yang diangkat dalam penelitian ini, maka di bawah ini diuraikan beberapa kajian teori-teori yang mendasari penelitian ini, diantaranya adalah 1) kecerdasan emosional; 2) kecerdasan spiritual; 3) pembelajaran Pendidikan Agama Islam Kurikulum 2013.

Kata emosi berasal dari bahasa latin, yaitu emovere, yang berarti bergerak menjauh. Arti kata ini menyiratkan bahwa kecenderungan bertindak merupakan hal mutlak dalam emosi. Menurut Daniel Goleman emosi merujuk pada suatu perasaan dan pikiran yang khas, suatu keadaan biologis dan psikologis dan serangkaian kecenderungan untuk bertindak (Goleman, 2007, p. 411). Emosi pada dasarnya adalah dorongan untuk bertindak. Biasanya emosi merupakan reaksi terhadap rangsangan dari luar dan dalam diri individu. Sebagai contoh emosi gembira mendorong perubahan suasana hati seseorang, sehingga secara fisiologi terlihat tertawa, emosi sedih mendorong seseorang berperilaku menangis. Emosi berkaitan dengan perubahan fisiologis dan berbagai pikiran. Jadi, emosi merupakan salah satu aspek penting dalam kehidupan manusia, karena emosi dapat merupakan motivator perilaku dalam arti meningkatkan, tapi juga dapat mengganggu perilaku intensional manusia (Prawira, 2012)

Kecerdasan emosi yang pada awalnya diperkenalkan Peter Salovey dari Harvard University dan John Mayer dari Universitas New Hampshire, dipopulerkan oleh Daniel Goleman lewat bukunya Emotonal Intelligence. Goleman mendefinisikannya "sebagai hal yang merujuk pada perasaan dan pikiran-pikiran khasnya, suatu keadaan biologis dan psikologis, dan serangkaian kecenderungan yang ada pada diri seseorang" (Goleman, 2007, p. 411). Keduanya Salovey dan Mayer menggunakan istilah emosi untuk menggambarkan sejumlah kemampuan mengenali emosi diri, mengelola dan mengekspresikannya dengan tepat, serta untuk memotivasi diri sendiri, dan menjalin hubungan dengan orang lain.

Kecerdasan emosional yang ditandai dengan ciri-ciri seperti; kemampuan untuk memotivasi diri sendiri. Kemampuan dorongan hati. Tidak melebihlebihkan kesenangan, mengatur suasana hati menjaga agar bebas stress, tidak melumpuhkan kemampuan berfikir, berempati dan giat berdoa diartikan sebagai konsep baru dalam psikologi ilmiah. Sebagai konsep baru, kecerdasan emosi masih belum dikemukakan dengan tepat, tentang variasi yang ditimbulkannya terhadap pengalaman seseorang.

Kehidupan emosional merupakan wilayah yang sama pastinya dengan matematika atau kemampuan baca, sehinga dapat ditangani dengan keterampilan yang lebih tinggi dan lebih rendah. Sementara yang dimaksud dengan keterampilan emosional adalah meta-ability, menentukan seberapa baik 
seseorang mampu menggunakan keterampilan-keterampilan lain yang dimiliki, termasuk intelektual yang belum terasah (Abdullah, 2002, p. 158). Lebih lanjut, sebagian pakar mengklasifikasikannya sebagai pekerja otak kanan, sedangkan otak kiri adalah kerja kecerdasan intelligence.

Menurut Bobi De Porter dalam (Pasiak, 2002, p. 135) "otak kanan manusia memiliki cara kerja yang acak, tidak teratur, intuitif, dan holistic serta memiliki kemampuan berpikir divergen, kreatif dan imajinatif. Sedangkan otak kiri memiliki cara kerja logis, rasional, sekuen, linear dan berkemampuan kovergen". Pada otak kanan manusia ada sel yang dinamakan amigdala. Amigdala adalah sumber terjadinya kecerdasan emosional, social, spasial, kinestetik, natural, intrapersonal dan interpersonal.

Paradigma otak kanan akan menghasilkan dunia yang lebih luas. Untuk memperoleh sesuatu yang lebih bermakna, manusia harus belajar melihat sesuatu secara terpadu (integral) dan menyeluruh (holistic). Cara berpikir linear yang tipikal otak kiri cukup baik, tetapi corak itu tidaklah cocok untuk menyelesaikan semua persoalan hidup yang dialami. Dalam hal ini, cara berpikir otak kiri sebenarnya telah banyak menolong manusia dalam menghadapi permasalahan hidupnya.

Begitu juga dalam dunia modern yang ditandai dengan perkembangan sains teknologi, penggunaan otak kiri dengan model berpikir linearnya sangat berperan dan telah menghasilkan sejumlah penemuan-penemuan berharga, termasuk komputer dan internet. Meskipun demikian, masih ada ilmuwan yang mengatakan bahwa linear manusia hanya menggunakan setengah otaknya. Artinya ada dua jaringan otak yang melahirkan dua macam kecerdasan yaitu kecerdasan intelektual dan emosional. Kemampuan kecerdasan emosi melahirkan rasa empati, cinta, motivasi, kesabaran, semangat tinggi, percaya diri, ketekunan dan keterampilan social. Hal ini sesuai dengan yang dinyatakan Supriadi dalam bukunya Dari IQ dan CQ ke EQ, yakni bahwa kecerdasan emosional adalah "kemampuan manusia yang berupa keterampilan emosional yang akan membentuk karakter termasuk di dalamnya pengendalian diri, empati dan optimisme" (Supriadi, 1997, p. 10).

Secara sederhana Ary Ginanjar Agustian mengartikan kecerdasan emosional adalah kemampuan merasakan. Dan cara meningkatkan ini adalah dengan cara mempraktekkannya (Agustian, 2007, p. 56). Dalam hal ini, dipahami bahwa perlu kiranya mengembangkan kecerdasan emosional. Dengan pengembangan EQ yang dimiliki seseorang menjadikannya mampu mengendalikan diri, mengatur hubungan dengan sosial kemasyarakatan, bersikap empati, bersikap jujur dan rendah hati. Sikap-sikap ini bertujuan mengharmoniskan hubungan antara sesama manusia, sebagai tahapan menuju kecerdasan spiritual, yakni buhungan dengan Tuhan. 
Selanjutnya mengenai kecerdasan spiritual, Danah Zohar mendudukkan kecerdasan spiritual sebagai kecerdasan puncak seteleh kecerdasan intelektual dan emosional (Zohar, 2002, p. 4). Marsha Sinetar dan Khalil Khavari dalam (Herawati \& Mulyanratna, 2014, p. 165) menyatakan SQ lebih relevan dengan perkembangan psikologi mutakhir, karena kecerdasan spiritual merupakan pikiran yang mendapat inspirasi, dorongan dan efektivitas yang terinspirasi, atau penghayatan ketuhanan yang di dalamnya manusia semua menjadi bagian.

Menurut Ary Ginanjar Agustian di dalam ESQ, kecerdasan spiritual adalah kemampuan untuk memberi makna ibadah terhadap setiap perilaku dan kegiatan, melalui langkah-langkah dan pemikiran yang bersifat fitrah, menuju manusia yang seutuhnya (hanif), dan memiliki pola pemikiran tauhidi (integralistik), serta berprinsip "hanya karena Allah" (Agustian, 2007, p. 57).

Dalam buku Revolusi IQ/EQ dan SQ, Taufiq Pasiak menyatakan terminology spiritual yakni Sebagai kecerdasan yang berkaitan dengan hal-hal transenden, hal-hal yang "mengatasi" waktu, melampaui kekinian dan pengalaman manusia. SQ bukanlah doktrin agama yang mengajak umat manusia untuk cerdas dalam memilih atau memeluk salah satu yang dianggap benar dalam perspektif barat. Kecerdasan spiritual merupakan sebuah konsep yang berhubungan dengan bagaimana seorang cerdas dalam mengelola dan mendayagunakan makna-makna, nilai-nilai dan kualitas-kualitas kehidupan spiritualnya. Kehidupan spiritual yang dimaksudkan meliputi hasyrat untuk hidup bermakna (the will to meaning) dan yang memotivasi kehidupan manusia untuk senantiasa mencari makna hidup (the meaning of life) (Mudzakir \& Mujib, 2001, p. 325).

Sebagai bagian dari psikologi, kecerdasan spiritual memandang bahwa seorang yang taat beragama belum tentu memiliki kecerdasan spiritual. Mereka kadang-kadang masih menerapkan sikap fanatisme, ekslusivisme dan intoleransi terhadap pemeluk agama lain, sehingga mengakibatkan permusuhan di antaranya. Sebaliknya bisa jadi seorang humanis non-agamis memiliki kecerdasan spiritual yang tinggi, sehingga sikap hidupnya bernuansa inklusif, menghargai pluralitas dan bersikap toleran (Mudzakir \& Mujib, 2001, p. 325).

Sebagai suatu potensi, kedudukan kecerdasan spiritual disikapi sebagai hal yang unik atau kontroversial. Ada yang berpendapat bahwa potensi spiritual berada pada hati qalb. Ada juga mengatakan bahwa kecerdasan spiritual ada pada otak. Dalam pandangan Barat, kecerdasan spiritual bukanlah bersumber pada hati atau qalb, tetapi bersumber dari otak yang dinamakan "God Spot". Otak manusia di samping memiliki kecerdasan intelektual, yaitu jaringan otak kiri, dan memiliki kecerdasan emosional pada jaringan otak kanan, juga memiliki kecerdasan spiritual yang berada pada noktah Tuhan (God Spot). Psikolog Barat berpandangan bahwa kecerdasan spiritual yang bertumpu pada 
otak manusia bermain secara anggun dalam kehidupan manusia sadar. Di samping pada God Spot, pada neurology dan neurokimia membuktikan bahwa spiritual inteligensi yang berbasis pada otak manusia juga bersumber dari osilasi $\mathrm{Hz}$, penanda somatic, dan bawah sadar kognitif (Pasiak, 2002, p. 124). Sebaliknya pemikir muslim berpandangan bahwa potensi spiritualitas bersumber pada hati yang juga disebut jantung (Mubarok, 2001, p. 48).

Dari qalb lahirlah kecerdasan spiritual yang menyebabkan seseorang cenderung menerima kebenaran dan kebaikan. Dalam bahasa al-Qur'an qalb yang memiliki kecenderungan kepada universalitas dikatakan sebagai basirah (mata hati) sebagai pecahan kata basara dan absara. Menurut para pakar tafsir, basirah bisa berarti mata batin atau akal sehat, yaitu akal yang jika digunakan secara optimum akan menghasilkan kebenaran, karena ia memilih kekuatan yang sekuat pandangan mata batin ('ainun basirah) pada seseorang yang memiliki al-'aql al-salim (akal sehat) (Mubarok, 2001, p. 40). Bashirah atau hati nurani senantiasa bersifat konsisten dan jujur.

Dalam hal ini terdapat perbedaan sumber SQ antara pandangan psikologi Barat dan Islam. Kalau dalam pandangan Barat kecerdasan spiritual bersumber dari otak yang bernama "God Spot", maka Islam menyatakannya dari hati. Perbedaan pandangan ini terjadi karena berbedanya cara pandang dan landasan berpijak. Barat yang masih apologi dengan wacana intelektualisme lebih meyakini bahwa potensi spiritual berada pada otak di kepala. Sebaliknya Islam yang berangkat dari tataran tekstualitas berkesimpulan bahwa kualitas spiritual berada pada qalb (hati) yang berada pada dada. Meskipun terjadi perbedaan di sekitar sumber kecerdasan spiritual, namun keduanya mengakui bahwa SQ adalah kecerdasan yang tertinggi dan berada dalam nurani terdalam.

Dalam bagian ini, penulis akan memaparkan beberapa karakteristik kecerdasan spiritual. Menurut Danah Zohar, di antara karakteristik kecerdasan spiritual adalah Mengenal motif yang paling dalam, memiliki tingkat kecerdasan yang tinggi, bersikap responsif pada diri yang dalam, mampu memanfaatkan dan mentransendenkan kesulitan, sanggup berdiri menentang atau berbeda dengan kerumunan, enggan mengganggu atau menyakiti, memperlakukan agama secara spiritual dan memperlakukan kematian secara spiritual (Zohar, 2002, p. 255).

Ciri pertama, "mengenal motif yang paling dalam". Karakteristik spiritual seperti ini merupakan pengindikasian kreatif. Motif kreatif adalah motif yang menghubungkan seseorang dengan kecerdasan spiritual. Motif kreatif tidak ada pada kreatifitas yang dikembangkan IQ. Kecerdasan intelektual hanya mampu membantu seseorang untuk menganalisis atau mencari pemecahan soal (problem solving) yang logis, ilmiah seperti untuk 
menjawab pertanyaan 4 x 4 sama dengan berapa. Bukan pula pada EQ, karena EQ sebagai fakultas atau kecerdasan, hanya membantu seseorang untuk bisa menyesuaikan diri, berempati, bersabar atau mengendalikan diri. Tetapi untuk bisa bermotivasi kreatif, seseorang memerlukan suatu kecerdasan yang dinamakan kecerdasan spiritual. Orang yang cerdas secara spiritual akan mampu mengetahui motifnya yang paling dalam.

Ciri kedua, "orang yang mempunyai tingkat kecerdasan diri yang tinggi". Seseorang tidak hanya mengenal dan menilai dirinya lebih baik, lebih bahagia, benar, diakui dan sejenisnya, karena selalu berusaha mengenal keadaan dirinya lebih lanjut secara mendalam. Seseorang misalnya, selalu bertanya-tanya, siapakah diri ini, dari mana asal dan mau kemana tujuannya?, sebab dengan mengenal diri ini (siapa, di mana, dari mana, mau kemana dan bagaimana keberadaannya), maka akan mengenal tujuan dan misi hidupnya. Setelah mengetahui apa tujuan hidupnya, maka ia akan berusaha menyusun rencana, persiapan, prinsip, strategi dan pendekatan untuk menggapai tujuan yang dicita-citakan. Rencana dan strategi yang dirumuskan itu terjadi sesuai dengen bisikan motifnya yang paling dalam.

Ciri ketiga, "bersikap responsif pada dirinya yang paling dalam". Dia sering melakukan refleksi dan mau mendengarkan dirinya. Biasanya seseorang akan responsif pada dirinya yang paling dalam ketika dalam keadaan musibah atau kesusahan. Sebaliknya banyak orang terlena, tidak mengenal siapa dan dari mana asalnya ketika dalam kesenangan. Sejarah membuktikan, banyak raja-raja besar karena terlena dengan kemegahan dan keindahan istana sehingga lalai dan mengabaikan tugas utamanya mengayomi rakyat dan masyarakat bawah. Berkenaan dengan ini, Danah Zohar juga menyatakan bahwa "kadangkadang manusia mulai mendengarkan suara hatinya ketika ditimpa penderitaan, kesulitan dan sejenisnya" (Zohar, 2002, p. 254).

Ciri keempat, "mampu memanfaatkan dan mentransendenkan kesulitan”. Dalam konteks ini, orang cerdas secara spiritual tidak pernah mencari kembing hitam ketika berhadapan dengan masalah, keteledoran atau kesulitan. Misalnya dengan mengatakan "saya dibesarkan oleh Ibu yang tidak sayang kepada saya, dan Bapak yang mengecewakan sepanjang hidup saya”. Menurut Jalaluddin Rakhmat tipe orang seperti ini diistilahkan dengan tipe "pandir spiritual' (menyalahkan pihak lain). Dia selalu mencari pembenaran, alasan untuk mengkambing hitamkan orang lain akan sikapnya yang ada. Seseorang yang cerdas secara spiritual merupakan gentleman, ksatria dan bertanggung jawab atas resiko hidup yang dihadapi. Dia bisa menerima kesulitan dalam bentuk apapun dan meletakkannya dalam rencana hidup yang lebih besar. Dia mengambil I'tibar dan makna dari segala kesulitan yagn 
dihadapi dan ia jadikan sebagai strategi untuk menggapai kemajuan di hari mendatang.

Ciri kelima, "mampu standing against the crow (menentang arus)". Salah satu ciri manusia modern adalah kecenderungannya mengikti trend, budaya dan gaya hidup modern. Perkembangan arus informasi yang sarat dengan budaya Barat, baik melalui media elektronika seperti TV, komputer, internet, maupun media cetak seperti surat kabar, jurnal, majalah dan sebagainya telah mempengaruhi manusia modern di manapun mereka berada. Dengan arus informasi ini kebanyakan orang dengan mudah terpengaruh terhadap trendtrend budaya yang disiarkan. Tetapi orang yang cerdas secara spiritual bukanlah orang yang mudah terpengaruh dengan arus informasi dan trend kebanyakan orang.

Ciri keenam, "merasa bahwa alam semesta ini adalah sebuah kesatuan", orang yang cerdas secara spiritual mengganggap bahwa ada keterkaitan antara sama-sama lainnya. Kalau dia menyakiti orang lain, nanti akibatnya pada dirinya juga, di mana terjadi polusi yang tak terhindarkan. Kalau ia berpribadi kasar terhadap murid-muridnya, maka ia dan anaknya akan dikasari orang lain juga. Jadi orang yang spiritually intelligent memiliki kecerdasan seperti ini, sehingga ia tidak melakukan sesuatu apapun kecuali perlakuan yang menyenangkan dan membahagiakan orang lain.

Ciri kecerdasan spiritual yang ketujuh, "orang yang memperlakukan agama secara spiritually intelligent". Orang yang cerdas secara spiritual tidak mesti orang beragama, tetapi orang yang tidak beragamapun kadang-kadang memiliki kecerdasan spiritual. Orang-orang yang keberagamaannya cerdas secara spiritual akan selalu menjalankan tradisi agamanya dengan setia, tetapi juga juga ia idak akan merasa bahwa agamanyalah yang paling benar. Dia tidak ekstrim atau fanatik terhadap agamanya, sehingga berani menyalahkan agama atau aliran orang lain. Agamawan yang cerdas secara spiritual senantiasa mengetahui bahwa jalan menuju Tuhan itu bermacam-macam. Karena inti dari keberagamaan itu sendiri adalah cinta; dan bahwa yang ia lakukan hanyalah tradisi yang diyakini paling cocok, tapi ia juga mengakui keberagamaan orang lain.

Kecerdasan spiritual memiliki beragam keistimewaan dibanding dengan kecerdasan lainnya (intellectual dan emotional quotient). Di antara kelebihan kecerdasan spiritual adalah; terletak pada segi prenial, hubungan dan fungsi atau kegunaannya. Kecerdasan spiritual mampu mengungkap segi prenial (yang abadi, asasi spiritual dan fitrah). Kecerdasan spiritual mampu mengenal hal-hal yang bersifat immaterial dan sisi-sisi hakikat manusia. Berbeda dengan kecerdasan intelektual dan emosional yang hanya mampu mengenal persoalan empiris dan diverifikasi ilmiah, kecerdasan spiritual bahkan mampu memenuhi 
dan mengenal persoalan abstrak, gaib dan misteri kematian sekalipun. Kecerdasan spiritual bukan hanya bersifat temporer dan dinamis seperti halnya kecerdasan intelektual dan emosional tetapi juga bersifat abadi dan absolut. Di sinilah kelebihan kecerdasan spiritual seperti yang disinyalir oleh Danah Zohar dan Ian Marshall dalam bukunya Spiritual Inteligent, yakni bahwa kedudukan kecerdasan spiritual merupakan sebagai sentral utama dari kecerdasankecerdasan lainnya (Zohar, 2002, p. 6).

Kecerdasan spiritual memiliki kemampuan untuk melahirkan kesehatan mental manusia. Dalam kehidupan modern, ketika manusia mengalami kemajuan ilmu pengetahuan dan teknologi yang ditandai dengan kemajuan alat transportasi, komunikasi dan informasi global, manusia dihadapkan kepada beragam krisis spiritual. Kemajuan intelektual yang bewujud ilmu pengetahun dan tekhnologi, yang tidak dibarengi dengan kemajuan emosional dan spiritual lebih menyebabkan lahirnya distorsi-distorsi nilai-nilai kemanusiaan. Kemajuan intelektual yang didak dibarengi dengan emosional dan spiritual akan menyebabkan ketidak mampuan manusia dalam mengarungi samudra atau hutan peradaban modern. Bahkan ketidak seimbangan antara intelektuan, emosional dan spiritual itu juga menyebabkan manusia modern mengalami kemiskinan spiritual yang ditandai dengan meningkatnya budaya egoisme, materialisme, dan hedonism.

Modernitas dengan segala kemajuan simbolitasnya lebih menyebabkan menggejalanya kekosongan dan kerapuhan jiwa manusia. Ketidak berdayaan manusia bermain dalam pentas peradaban modern yang terus melaju tanpa dapat dihentika itu lebih menyebabkan sebagian besar "manusia" terperangkap dalam siatuasi yang menurut Psikolog Humanis terkenal, Rollo May dalam (Mubarok, 2001, p. 17) disebut sebagai "manusia dalam kerangkeng". Yakni manusia yang sudah kehilangan makna, manusia kosong, The Hollow Man. Tipe manusia yang selalu resah setiap kali mengambil keputusan, tidak tahu apa yang diinginkan, dan tidak mempu memilih jalan hidup yang diinginkan. Manusia seperti ini mengidap gejala keterasingan, alienasi, yang disebabkan oleh perubahan sosial yang cukup pesat, hubungan antar sesama yang gersang, stabilitas siosial yang berubah menjadi mobilitas dan factor-faktor lainnya. Era inilah yang menurut Elizabeth Lucas seperti yang dikutip Achmad Mubarok dikategorikan sebagai era kebebasan (freedom) dalam hampir semua bidang kehidupan.

Mengobati semua penyakit spiritual ini yang umumnya diderita manusia modern, tidaklah mungkin dengan menggunakan kecerdasan intelektual dan emosional semata karena keduanya tidak menyentuh persoalan spiritual manusia. Kecerdasan intelektual di satu sisi dan kecerdasan emosional di sisi lain belum mampu menyelesaikan beragam krisis spiritual yang dialami 
manusia modern itu. Hal ini logis karena kedua kecerdasan itu hanya berkisar pada persoalan empiris dan kepribadian seseorang. Lain halnya dengan kecerdasan spiritual, bukan hanya menyentuh bagian empiris, kepribadian dan spiritual kita, lebih dari itu juga mampu menyajikan beragam resep mulai dari pengalaman spiritual (spiritual experience), sampai penyembuhan spiritual (spiritual healing) sehingga kita benar-benar mengalami segi-segi kesehatan spiritual. Kecerdasan spiritual mampu menjadikan keamanan bagi seseoran, kedamaian, penuh cinta, dan merasa bahagia, dibandingkan ketika seseorang tidak memiliki kecerdasan spiritual akan mengalami suasana yang tidak nyaman, tidak bahagia dan tidak memiliki rasa cinta.

Kecerdasan spiritual juga mampu menciptakan kehidupan bermakna sebagai refleksi dari kebahagiaan hidup seseorang. IQ dan EQ tidak mampu mengantarkan seseorang kepada kebahagiaan hakiki, karena keduanya lebih bersifat material dan duniawi. Mengejar hal-hal yang materi dan syahwati tidaklah pernah memberikan ketenangan dan kepuasan bagi seseorang dalam hidup dan kehidupannya. Hal ini karena sifat materi itu adalah temporer (sementara). Bertumpu pada material semata tidak mampu menjadikan seseorang bahagia atau mengalami hidup bermakna. Kearifan seseorang tercernin melalui sikap kejujuran, keadilan, toleransi, keterbukaan, penuh cinta dan kekasih sayangannya terhadap sesama tanpa memandang sekat-sekat yang bersifat ekslusif (Puluhulawa, 2013, p. 141).

Keutamaan kecerdasan spiritual di atas mengindikasikan akan perlunya penelitian lebih lanjut di sekitar implementasi pembelajaran berbasis kecerdasan emosional dan spiritual. Implementasi yang dimaksudkan adalah tentang prinsip-prinsip, materi atau subjek pelajaran, metode dan langkahlangkah pembelajaran berbasis kecerdasan emosional dan spiritual.

Selanjutnya konsep pendidikan agama Islam, kata "pendidikan" yang umum digunakan sekarang dalam bahasa Arabnya adalah "Tarbiyah" dengan kata kerja "rabba". Sedangkan pendidikan Islam bahasa Arabnya adalah "Tarbiyah Islamiyah". Dalam ayat Al-Qur'an kata ini digunakan dalam susunan sebagai berikut:

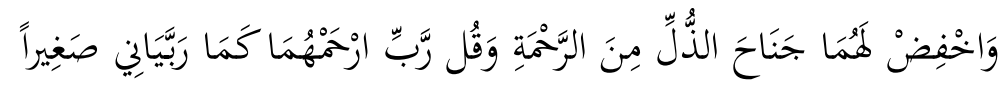

Dan rendahkanlah dirimu terhadap mereka berdua dengan penuh kesayangan dan ucapkanlah: "Wahai Tuhanku, kasihilah mereka keduanya, sebagaimana mereka berdua telah mendidik aku waktu kecil. (QS. Al-Isra' $16: 24)$

Kata "ta'lim" berasal dari kata kerja "allama” yang berarti pengajaran. Pendidikan dan pengajaran dalam bahasa Arabnya adalah "Tarbiyah wa Ta'lim”. Dari segi bahasa, perbedaan arti dari kedua kata itu cukup jelas, namun yang lebih banyak digunakan dalam Al-Qur'an, Hadis, atau pemakaian sehari-hari adalah kata "ta'lim" daripada kata "tarbiyah". 


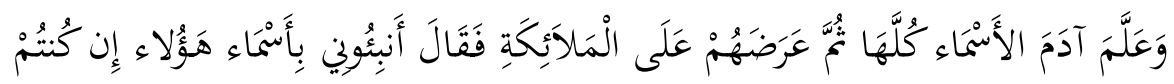

صَادِقِنَنَ

Dan Dia mengajarkan kepada Adam nama-nama (benda-benda) seluruhnya, kemudian mengemukakannya kepada para Malaikat lalu berfirman: "Sebutkanlah kepada-Ku nama benda-benda itu jika kamu mamang benar orang-orang yang benar. (QS. AlBaqarah $2: 31$ )

Pendidikan, dalam arti umum mencakup segala usaha dan perbuatan dari generasi tua untuk mengalihkan pengalamannya, pengetahuannya, kecakapannya serta keterampilannya kepada generasi muda untuk memungkinnya melakukan fungsi hidupnya dalam pergaulan bersama, dengan sebaik-baiknya (Ali, 1993, p. 8).

Pendidikan dalam Islam, antara lain berusaha untuk mengembangkan alat-alat potensial dari manusia tersebut seoptimal mungkin untuk dapat difungsikan sebagai sarana bagi pemecahan masalah-masalah hidup dan kehidupan, pengembangan ilmu pengetahuan dan teknologi serta budaya manusia, dan pengembangan sikap iman dan takwa kepada Allah Swt. (Muhaemin, 2004, p. 16).

Pengertian pendidikan bahkan lebih diperluas cakupannya sebagai aktivitas dan fenomena. Pendidikan sebagai aktivitas berarti upaya yang secara sadar dirancang untuk membantu sesorang atau sekelompok orang dalam mengembangkan pandangan hidup (bagaimana manusia akan menjalani dan memanfaatkan hidup dalam kehidupannya), sikap hidup, dan keterampilan hidup, baik yang bersifat manual (petunjuk praktis) maupun mental dan sosial. Sedangkan pendidikan sebagai fenomena adalah peristiwa perjumpaan antara dua orang atau lebih yang dampaknya ialah berkembangnya suatu pandangan hidup, sikap hidup atau keterampilan hidup pada salah satu atau beberapa pihak (Muhaemin, 2004, p. 16).

Jadi pendidikan merupakan suatu proses yang dilakukan oleh masyarakat dalam rangka untuk mempersiapkan generasi seterusnya agar dapat bersosialisasi dan beradaptasi serta memecahkan berbagai persoalan dalam kehidupan sosial mereka, karena pendidikan merupakan bagian dari strategi dalam kehidupan. Proses penyesuaian manusia terhadap masyarakat dan lingkungannya, dengan semua ruang lingkup yang terdapat didalamnya. Namun demikian proses tersebut bukan merupakan suatu hal yang sangat mudah, mengingat akan kemampuan yang terbatas pada diri manusia itu sendiri.

Dunia pendidikan memang selalu dinamis, terus mengalami perubahanperubahan menuju kesempurnaannya, baik untuk beradaptasi dengan ruang dan waktu yang mengitarinya, maupun untuk mempersiapkan diri dengan 
masa yang akan datang. Pendidikan dengan karakter mnyesuaikan diri dengan kebutuhan masyrakat dan global merupakan mereka penganut paham progressivisme. Mereka meyakini bahwa subjek didik mempunyai suatu keinginan alami untuk belajar dan menemukan hal-hal tentang dunia dan sekelilingnya. Sedangkan mereka para penganut futurisme, menjadikan pendidikan sebaga alat untuk memproyeksikan masa depan. Yaitu dengan menjadikan mata pelajaran dalam pendidikan adalah untuk menjaga agar proses pendidikan tetap hidup, dan menjaganya dengan cara yang dapat menimbulkan kemudahan dalam menghadapi masa depan.

Jika perubahan merupakan sebuah keniscayaan yang tidak dapat dihindari maka perubahan itu pun tidak dapat di arahkan hanya kepada sebagian sub pendidikan saja, melainkan menyasar seluruh aspek pendidikan, dalam hal ini tidak terkecuali kepada kurikulum sebagai sebuah kerangka program dalam melaksanakan sebuah proses pendidikan. Dalam konteks Indonesia, perubahan kurikulum sudah beberapa kali mengalami perubahan. Dalam catatan sejarah sejak tahun 1945, kurikulum di Indonesia telah mengalami perubahan, yaitu pada tahun 1947 (dengan nama Kurikulum Rencana Pelajaran), 1952 (dengan nama Kurikulum Rencana Pelajaran Terurai), 1964 (dengan nama Kurikulum Rencana Pendidikan), 1968, 1975, 1984, 1994, (yang masing-masing menggunakan tahun sebagai nama kurikulum), 2004 (dengan nama Kurikulum Berbasis Kompetensi), 2006 (dengan nama Kurikulum Tingkat Satuan Pendidikan), dan yang terbaru adalah kurikulum 2013 atau yang lebih dikenal dengan sebutan K-13.

Dikarenakan pendidikan Islam merupakan subsistem dari pendidikan nasional, maka ketika pendidikan nasional mengalami pengembangan kurikulum, maka secara otomatis pendidikan Islam akan menyesuaikan dengan kurikulum terbaru. Dengan semangat pembaruan dan pengembangan kurikulum banyak sekali para pemikir Islam yang menawarkan konsep pengembangan kurikulum pendidikan Islam.

Menurut Undang-Undang Nomor 20 Tahun 2003 tentang Sistem Pendidikan Nasional, bahwa pendidikan nasional berfungsi mengembangkan kemampuan dan membentuk watak serta peradaban bangsa yang bermartabat dalam rangka mencerdaskan kehidupan bangsa, bertujuan untuk berkembangnya potensi peserta didik agar menjadi manusia yang beriman dan bertakwa kepada Tuhan Yang Maha Esa, berakhlak mulia, sehat, berilmu, cakap, kreatif, mandiri, dan menjadi warga negara yang demokratis serta bertanggung jawab dalam segala urusan yang menjadi tanggung jawabnya.

Dalam problematis penerapan kurikulum pendidikan, Indonesia merupakan negara yang sering mengalami pergantian perangkat bahan studi tersebut. Sehingga untuk mempertahankan asas fungsionalitas, diskursus mata 
pelajaran Pendidikan Agama Islam menjadi bahan kajian yang relevan kini, sebab perannya yang urgen dalam peningkatan aspek kognitif, afektif dan psikomotorik manusia (Hasyim, 2015, p. 107).

Pendidikan Agama Islam sebagai mata pelajaran yang wajib ditempuh oleh peserta didik mulai dari jejak lahir sampai meninggal menjadi bahan kajian berkelanjutan dalam kehidupan. Oleh karena itu perlu untuk memahami hakikat kurikulum pendidikan, khususnya pada kurikulum PAI. Prosesi perumusan kurikulum tentunya tidak serta merta memunculkan produk yang sesuai sebagai alat yang dapat mencerdaskan manusia. Tetapi perlu usaha lebih untuk memanifestasikan epistemologi ke-Islaman menjadi aksiologis rahmatan lil alamin (Hasyim, 2015, pp. 107-108). Dalam Kurikulum Madrasah di Kementerian Agama, implementasi Kurikulum PAI dituangkan dalam bentuk Mata Pelajaran Fiqih, Aqidah Akhlak, Al-Quran Hadits, Ilmu Kalam, Akhlak, Ilmu Tafsir, Ilmu Hadits, dan Sejarah Kebudayaan Islam.

Kehadiran Kurikulum 2013 sudah menyesuaikan dengan keadaan zaman yang sekarang, artinya penguatan nilai spiritual dan sosial sudah harus dimiliki oleh peserta didik akan memperbaiki sistem kehidupan berbangsa dan bernegara. Sesuai dengan Pasal 2 Undang-Undang Nomor 20 Tahun 2003 tentang Sistem Pendidikan Nasional, bahwa pendidikan nasional berdasarkan Pancasila dan Undang-Undang Dasar Negara Republik Indonesia Tahun 1945. Sedangkan Pasal 3 menegaskan bahwa pendidikan nasional berfungsi mengembangkan kemampuan dan membentuk watak serta peradaban bangsa yang bermartabat dalam rangka mencerdaskan kehidupan bangsa, bertujuan untuk mengembangkan potensi peserta didik agar menjadi manusia yang beriman dan bertakwa kepada Tuhan Yang Maha Esa, berakhlak mulia, sehat, berilmu, cakap, kreatif, mandiri, dan menjadi warga negara yang demokratis serta bertanggung jawab. Adapun tujuan Standar Kompetensi Lulusan (SKL) digunakan sebagai acuan utama pengembangan standar isi, standar proses, standar penilaian pendidikan, standar pendidik dan tenaga kependidikan, standar sarana dan prasarana, standar pengelolaan, dan standar pembiayaan.

Standar Isi adalah kriteria mengenai ruang lingkup materi dan tingkat kompetensi untuk mencapai kompetensi lulusan pada jenjang dan jenis pendidikan tertentu. Ruang lingkup materi dan tingkat kompetensi peserta didik yang harus dipenuhi atau dicapai pada suatu satuan pendidikan dalam jenjang dan jenis pendidikan tertentu dirumuskan dalam Standar Isi untuk setiap mata pelajaran. Standar Isi disesuaikan dengan substansi tujuan pendidikan nasional dalam domain sikap spritual dan sikap sosial, pengetahuan, dan keterampilan. Oleh karena itu, Standar Isi dikembangkan untuk menentukan kriteria ruang lingkup dan tingkat kompetensi yang sesuai 
dengan kompetensi lulusan yang dirumuskan pada Standar Kompetensi Lulusan, yakni sikap, pengetahuan, dan keterampilan.

Karakteristik, kesesuaian, kecukupan, keluasan dan kedalaman materi ditentukan sesuai dengan karakteristik kompetensi beserta proses pemerolehan kompetensi tersebut. Ketiga kompetensi tersebut memiliki proses pemerolehan yang berbeda. Sikap dibentuk melalui aktivitas-aktivitas: menerima, menjalankan, menghargai, menghayati, dan mengamalkan.

Pengetahuan dimiliki melalui aktivitas-aktivitas: mengetahui, memahami, menerapkan, menganalisis, mengevaluasi, dan mencipta. Keterampilan diperoleh melalui aktivitas-aktivitas: mengamati, menanya, mencoba, menalar, menyaji, dan mencipta. Karakteristik kompetensi beserta perbedaan proses perolehannya mempengaruhi Standar Isi (review Keputusan Menteri Agama Nomor 165 tahun 2014 BAB III).

Proses Pembelajaran pada satuan pendidikan diselenggarakan secara interaktif, inspiratif, menyenangkan, menantang, memotivasi peserta didik untuk berpartisipasi aktif, serta memberikan ruang yang cukup bagi prakarsa, kreativitas, dan kemandirian sesuai dengan bakat, minat, dan perkembangan fisik serta psikologis peserta didik (Permendikbud RI. nomor 65 tahun 2013 BAB I). Kegiatan pembelajaran merupakan proses pendidikan yang memberikan kesempatan kepada peserta didik untuk mengembangkan potensi mereka menjadi kemampuan yang semakin lama semakin meningkat dalam sikap, pengetahuan, dan keterampilan yang diperlukan dirinya untuk hidup dan untuk bermasyarakat, berbangsa, serta berkontribusi pada kesejahteraan hidup umat manusia. Oleh karena itu, kegiatan pembelajaran diarahkan untuk memberdayakan semua potensi peserta didik menjadi kompetensi yang diharapkan.

Lebih lanjut, strategi pembelajaran harus diarahkan untuk memfasilitasi pencapaian kompetensi yang telah dirancang dalam dokumen kurikulum agar setiap individu mampu menjadi pebelajar mandiri sepanjang hayat. dan yang pada gilirannya mereka menjadi komponen penting untuk mewujudkan masyarakat belajar. Kualitas lain yang dikembangkan kurikulum dan harus terealisasikan dalam proses pembelajaran antara lain kreativitas, kemandirian, kerja sama, solidaritas, kepemimpinan, empati, toleransi dan kecakapan hidup peserta didik guna membentuk watak serta meningkatkan peradaban dan martabat bangsa.

Proses pembelajartan itu mungkin saja terjadi akibat dari stimulus dari luar yang diberikan guru, teman, lingkungan. Proses tersebut mungkin pula terjadi akibat dari stimulus dalam diri peserta didik yang terutama disebabkan oleh rasa ingin tahu. Proses pembelajaran dapat pula terjadi sebagai gabungan dari stimulus luar dan dalam. Dalam suatu kegiatan belajar dapat terjadi 
pengembangan sikap, pengetahuan, dan keterampilan dalam kombinasi dan penekanan yang bervariasi. Setiap kegiatan belajar memiliki kombinasi dan penekanan yang berbeda dari kegiatan belajar lain tergantung dari sifat muatan yang dipelajari. Meskipun demikian, pengetahuan selalu menjadi unsur penggerak untuk pengembangan kemampuan lain. Kegiatan pembelajaran, dalam implemenasinya mengenal banyak istilah untu menggambarkan cara mengajar yang akan dilakukan oleh guru. Saat ini banyak macam strategi ataupun metode pembelajaran yang bertujuan untuk meningkatkan kualitas pembelajaran menjadi lebih baik (Rusman, 2009, p. 131).

Karakteristik pembelajaran pada setiap satuan pendidikan terkait erat pada Standar Kompetensi Lulusan dan Standar Isi. Standar Kompetensi Lulusan memberikan kerangka konseptual tentang sasaran pembelajaran yang harus dicapai. Standar Isi memberikan kerangka konseptual tentang kegiatan belajar dan pembelajaran yang diturunkan dari tingkat kompetensi dan ruang lingkup materi. Sesuai dengan Standar Kompetensi Lulusan, sasaran pembelajaran mencakup pengembangan ranah sikap (spiritual dan sosial), pengetahuan (kognitif), dan keterampilan (psikomotorik) yang dielaborasi untuk setiap satuan pendidikan. Proses pembelajaran sepenuhnya diarahkan pada pengembangan ketiga ranah tersebut secara utuh, artinya pengembangan ranah yang satu tidak bisa dipisahkan dengan ranah lainnya. Dengan demikian proses pembelajaran secara utuh melahirkan kualitas pribadi yang mencerminkan keutuhan penguasaan sikap, pengetahuan, dan keterampilan (Permendikbud RI. nomor 65 tahun 2013 BAB II).

Kurikulum 2013 mengembangkan dua modus proses pembelajaran yaitu proses pembelajaran langsung dan proses pembelajaran tidak langsung. Proses pembelajaran langsung adalah proses pendidikan di mana peserta didik mengembangkan pengetahuan, kemampuan berpikir dan keterampilan psikomotorik melalui interaksi langsung dengan sumber belajar yang dirancang dalam silabus dan RPP berupa kegiatan-kegiatan pembelajaran. Dalam pembelajaran langsung tersebut peserta didik melakukan kegiatan belajar mengamati, menanya, mengumpulkan informasi, mengasosiasi atau menganalisis, dan mengkomunikasikan apa yang sudah ditemukannya dalam kegiatan analisis. Proses pembelajaran langsung menghasilkan pengetahuan dan keterampilan langsung atau yang disebut dengan instructional effect. Pembelajaran saintifik reputasinya melejit ke papan atas melebihi popularitas Contextual Teaching Learning (CTL) dan Cooperative Learning (CL). Bahkan CTL mendapatkan rekomendasi dari komisi UNESCO terkait "the four pillars of education" (Yani, 2014, p. 121).

Pembelajaran tidak langsung adalah proses pendidikan yang terjadi selama proses pembelajaran langsung tetapi tidak dirancang dalam kegiatan 
khusus. Pembelajaran tidak langsung berkenaan dengan pengembangan nilai dan sikap. Berbeda dengan pengetahuan tentang nilai dan sikap yang dilakukan dalam proses pembelajaran langsung oleh mata pelajaran tertentu, pengembangan sikap sebagai proses pengembangan moral dan perilaku dilakukan oleh seluruh mata pelajaran dan dalam setiap kegiatan yang terjadi di kelas, sekolah, dan masyarakat (review Keputusan Menteri Agama Nomor 165 tahun 2014 BAB IV).

Oleh karena itu, dalam proses pembelajaran Kurikulum 2013, semua kegiatan yang terjadi selama belajar di sekolah dan di luar dalam kegiatan kokurikuler dan ekstrakurikuler terjadi proses pembelajaran untuk mengembangkan moral dan perilaku yang terkait dengan sikap.

Standar penilaian pendidikan adalah kriteria mengenai mekanisme, prosedur, dan instrumen penilaian hasil belajar peserta didik. Penilaian pendidikan sebagai proses pengumpulan dan pengolahan informasi untuk mengukur pencapaian hasil belajar peserta didik. Salah satu kompetensi yang harus dimiliki oleh seorang guru adalah evaluasi pembelajaran. Termasuk di dalamnya melaksanakan penilaian proses dan hasil belajar (Daryanto \& Amirono, 2016, p. 1). Evaluasi pembelajaran diakukan untuk mengevaluasi kegiatn atau mengoreksi hal-hal yang terlah terjadi atau dilakukan selama pembelajaran yang telah terjadi (Daryanto \& Amirono, 2016, p. 3).

Sebagai ajaran yang integral dan sempurna, agama Islam memberikan perhatian terhadap sistem penilaian pendidikan. Al-Qur`an mengajarkan kepada umat Islam, bahwa penilaian terhadap peserta didik merupakan tugas penting dalam rangkaian proses pendidikan yang dilaksanakan. Isyarat ini dinyatakan Allah dalam firman-Nya Surat al-Baqarah ayat 31-32 sebagai berikut;

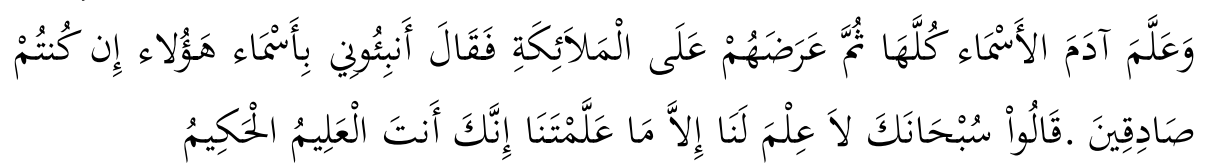

Dan Dia mengajarkan kepada Adam nama-nama (benda-benda) seluruhnya, kemudian mengemukakannya kepada para Malaikat lalu berfirman: "Sebutkanlah kepada-Ku nama benda-benda itu jika kamu mamang benar orang-orang yang benar!. Mereka menjawab: "Maha Suci Engkau, tidak ada yang kami ketahui selain dari apa yang telah Engkau ajarkan kepada kami; sesungguhnya Engkaulah Yang Maha Mengetahui lagi Maha Bijaksana. (QS. Al-Baqarah (2) 31-32)

Dari ayat tersebut bisa dijelaskan bahwa: 1) Allah SWT telah bertindak sebagai pendidik yang memberikan pelajaran kepada Nabi Adam. 2) Karena Malaikat tidak menerima pelajaran sebagaimana yang diterima Adam, maka ia tidak dapat menyebutkan isi pelajaran yang diberikan kepada Adam. 3) Allah meminta Nabi Adam agar mendemonstrasikan pelajaran yang diterimanya di hadapan para malaikat. 4) Mengisyaratkan perlunya penilaian dilakukan secara 
sistematis, konsisten dan sesuai dengan materi yang telah diajarkan pada proses pembelajaran.

Dalam review Keputusan Menteri Agama Nomor 165 tahun 2014 dijelaskan bahwa Standar Penilaian sebagai salah satu Standar Nasional Pendidikan yang bertujuan untuk menjamin: 1) perencanaan penilaian peserta didik sesuai dengan kompetensi yang akan dicapai dan berdasarkan prinsipprinsip penilaian; 2) pelaksanaan penilaian peserta didik secara profesional, terbuka, edukatif, efektif, efisien, dan sesuai dengan konteks sosial budaya; dan 3) pelaporan hasil penilaian peserta didik secara objektif, akuntabel, dan informatif. Adapun secara prinsip, untuk memperoleh hasil umum evaluasi yang baik, maka kegiatan penilaian (evaluasi) harus bertumpu pada prinsip umum yang meliputi 1) Kontinuitas, 2) komprehensif, 3) Adil dan objektif, 4) Kooperatif dan 5) Praktis (Daryanto \& Amirono, 2016, pp. 15-16).

\section{Metode}

Pendekatan yang digunakan dalam penelitian ini adalah pendekatan kualitatif. Sementara itu, metode yang digunakan adalah metode penelitian kepustakaan. Penelitian ini membatasi hanya pada kajian pustaka semata. Paling tidak ada tiga alasan kenapa melakukan hal ini. Pertama, karena persoalan penelitian tersebut hanya bisa dijawab lewat penelitian pustaka dan tidak bisa mengharapkan datanya dari penelitian lapangan. Kedua, studi pustaka ini diperlukan sebagai satu tahap tersendiri yaitu studi pendahuluan untuk memahami gejala baru yang terjadi dalam dunia pendidikan Islam. Ketiga, data pustaka tetap andal untuk menjawab persoalan penelitian ini.

Menurut Mestika Zed, ada empat ciri utama studi kepustakaan. Pertama: peneliti berhadapan langsung dengan teks dan data angka dan bukannya dengan pengetahuan langsung dari lapangan atau saksi mata berupa kejadian, orang atau benda-benda lain. Kedua, data pustaka bersifat siap pakai. Ketiga: data pustaka umumnya adalah sumber sekunder yang bukan data orisinil dari tangan pertama di lapangan. Keempat: kondisi data pustaka tidak dibatasi oleh ruang dan waktu. Masih menurut Mestika Zed bahwa banyak ahli yang menganggap bahwa penelitian perpustakaan identik dengan buku-buku. Anggapan ini tidak salah namun selain buku-buku ada juga data yang berupa dokumen, naskah kuno dan bahan non cetak lainnya (Zed, 2008, p. 4). Jadi, perpustakaan juga menyimpan karya non cetak seperti kaset, video, microfilm, mikrofis, disket, pita magnetik, selongsong elektronik dan lainnya. Berbagai jenis koleksi perpustakaan ini disimpan berdasarkan klasifikasi tertentu. Salah satu sistem klasifikasi yang umum digunakan adalah Sistem Dewey. Selain Sistem Dewey masih ada lagi sistem Library of Congress. Tetapi apa pun sistem 
klasifikasi yang dipakai, peneliti harus mengenal beberapa koleksi terpilih yang dalam studi pustaka sering disebut alat bantu bibliografis. Yang termasuk ke dalam alat bantu bibliografis adalah: Buku-buku referensi (kamus, ensiklopedi, buku indeks, buku bibliografi yang berisi informasi soal aspek tertentu, buku tahunan, buku atlas, buku direktori, kamus biografi, koleksi khusus seperti kliping dan lainnya), bibliografi buku-buku teks, indeks jurnal ilmiah, indeks buletin dan majalah, indeks surat kabar dan tabloid, indeks dokumen, indeks manuskrip, dan sumber-sumber lainnya.

Penelitian ini adalah penelitian (library research) yang berusaha mengkaji dan menganalisis pemikiran Ary Ginanjar Agustian tentang Kecerdasan Emotional Dan Spiritual Quotient (ESQ) Dalam Proses Pembelajaran Pendidikan Agama Islam. Menurut Sutrisno Hadi adalah suatu riset kepustakaan atau penelitian kualitatif murni (Sukardi, 2003:9) pada penelitian ini dilakukan kajian mendalam berupa historis, metodologis, analisis kritis atas buku-buku yang terkait dengan muatan Kurikulum 2013 Pendidikan Agama Islam. Penelitian juga dilakukan atas buku-buku lain sebagai studi komparatif dan perbandingan pemikiran yang berhubungan dengan judul.

Menurut jenis dan pengolahan datanya, penelitian ini termasuk penelitian kualitatif. Melalui penelitian kualitatif, penelitian terhadap pemikiran dan konsep akan dapat terjangkau berbagai makna dan fenomena yang lebih substantif dan mendalam mengenai konsep atau ide-ide. Metode analisis yang dipakai adalah deskriptif.

Metode deskriptif dimaksudkan bahwa pemikiran tentang implementasi kurikulum 2013 Pandidikan Agama Islam diuraikan kembali, ditelaah dan dipahami perkembangannya untuk dikaji lebih mendalam. Metode deskriptif di sini berfungsi bukan hanya untuk memaparkan konsep kurikulum yang didalamnya memuat konsep pembelajaran Pendidikan Agama Islam, tetapi juga membuat klasifikasi dan kategorisasi dengan mengelompokkan menjadi data dan bisa dimasukkan pada Emotional Quotient (EQ) dan Spiritual Quotient (SQ) dan efektifitas dari metode yang digunakan dalam penerapan aspek-aspek Emotional Spiritual Quotient (ESQ) dalam proses pembelajaran Pendidikan Agama Islam Kurikulum 2013.

Data yang akan dikumpulkan dalam artikel ini atas dasar sumber primer, data sekunder dan data pendukung (Moleong, 2010, p. 171). Data primer adalah data yang secara langsung diambil dari objek penelitian oleh peneliti baik secara perorangan maupun organisasi dari sumber utama (Suryabrata, 2014, p. 26). Data primer dalam penelitian ini adalah Emotional Intelligence karya Daniel Goleman; SQ: Memanfaatkan Kecerdasan Spiritual Dalam Berfikir Integralistik dan Holistik Untuk Memaknai Kehidupan karya Danah Zohar dan Ian Marshal; dan Pengembangan Dan Implementasi Kurikulum 2013 karya 
Mulyasa. Selain sumber primer tersebut sumber data skunder juga digunakan, yakni karya orang lain/penulis lain mengenai Emotional Spiritual Quotient (ESQ), pembelajaran Kurikulum 2013 Pendidikan Agama Islam.

Sedangkan yang dimaksud dengan data skunder adalah data yang didapat secara langsung dari objek penelitian, biasanya berupa dokumen (Suryabrata, 2014, p. 39). Dalam penelitian ini yang menjadi data skunder adalah karya-karya atau buku-buku penunjang yang berkaitan dengan ESQ yaitu buku tentang Intelligent Qoutinent (IQ), Emotional Quotient (EQ) dan Spiritual Quotient (SQ) dengan tujuan untuk mempermudah dan memperkuat isi tulisan dalam artikel ini. Pentingnya sumber skunder dalam penelitian ini adalah untuk menganalisis lebih mendalam tentang peranan ESQ dalam pembelajaran Pendidikan Agama Islam.

Mengingat penelitian ini termasuk studi kepustakaan atau library reseach, maka sebagian besar tugas peneliti adalah mencari bahan-bahan di perpustakaan, mencari dan menyurat dari bermacam-macam bahan tertulis yang berhubungan dengan permasalahan yang hendak diteliti (Sukardi, 2005, p. 34). Pada penelitian ini dilakukan dengan cara membaca, menelaah dan memahami beberapa sumber antara lain: buku-buku, karya ilmiah, jurnal, dan sumber lainnya, dengan tujuan mempermudah memperoleh data.

Adapun teknik analisis data yang digunakan adalah content analysis yaitu analisis ilmiah tentang isi pesan dalam sebuah karya, yakni menganalisis dan menterjemahkan apa yang telah disampaikan oleh pakar, baik melalui tulisan atau pesan yang berkenaan dengan apa yang dikaji. Dalam upaya menampilkan analisis ini harus memenuhi tiga kriteria, obyektif, pendekatan sistematis generalisasi, dan analisis harus berlandaskan aturan yang dirumuskan secara eksplisit. Analisis isi dapat dipergunakan jika memiliki syarat berikut. (1) Data yang tersedia sebagian besar terdiri dari bahan-bahan yang terdokumentasi (buku, surat kabar, pita rekaman, naskah/manuscrip). (2) Ada keterangan pelengkap atau kerangka teori tertentu yang enerapkan tentang dan sebagai metode pendekatan terhadap data tersebut. (3) Peneliti memiliki kemampuan teknis untuk mengolah bahan-bahan/data-data yang dikumpulkannya karena sebagian dokumentasi tersebut bersifat sangat khas/spesifik (Pawito, 2008, p. 293).

Sumber data yang dapat digunakan dalam analisis isi punberagam. Pada prinsipnya, apapun yang tertulis dapat dijadikan sebagai data dan dapat diteliti dalam analisis isi. Analisis isi memiliki prosedur yang spesifik, yang agak berbeda dengan metode penelitian yang lain. Beberapa prosedur analisis isi yang biasa dilakukan adalah sebagai berikut; (1) perumusan masalah: analisis isi dimulai dengan rumusan masalah penelitian yang spesifik, misalnya bagaimana kualitas pemberitaan surat kabar di indonesia; (2) pemilihan media (sumber 
data): peneliti harus menentukan sumber data yang relevan dengan masalah penelitian. suatu observasi yang mendalam terhadap perpustakaan dan berbagai media massa seringkali dakan membantu penentuan sumber data yang relevan. penentuan periode waktu dan jumlah media yang diteliti (sample), bila jumlahnya berlebihan, juga penting untuk ditentukan pada tahap ini; (3) definisi operasional: definisi operasional ini berkaitan dengan unis analisis. penentuan unit analisis dilakukan berdasarkan topik atau masalah riset yang telah ditentukan sebelumnya; (4) penyusunan kode dan mengecek reliabilitas: kode dilakukan untuk mengenali ciri-ciri utama kategori. idealnya, dua atau lebih coder sebaikya meneliti secara terpisah dan reliabilitasnya dicek dengan cara membandingkan satu demi satu kategori; (5) analisis Data dan Penyusunan Laporan: Data kualitatif yang diperoleh dengan analisis isi dapat dianalisis dengan deskriptif yang baku. Penulisan laporan dapat menggunakan format akademis yang cenderung baku dan menggunakan prosedur yang ketat atau dengan teknik pelapora populer versi media massa atau buku. Data dianalisis juga dalam bentuk Coding Sheets (Pawito, 2008, p. 295).

Dalam penelitian ini, yang diungkap dengan analisisnya adalah tentang makna data yang akan dibahas lebih rinci dalam pengumpulan data. Analisis data adalah proses mengatur urutan data, mengorganisasikan ke dalam suatu pola, kategori dan satuan uraian dasar atau menyusun dan menginterpretasikan data yang sudah didapat, menganalisa data merupakan bagian yang sangat penting, karena pada bagian inilah data dapat memberikan arti dan makna untuk memecahkan masalah. Maka untuk mengumpulkan data dan analisis dilakukan melalui langkah-langkah sebagai berikut: (1) Mengkaji kemudian menganalisis konsep Emotional Quotient (EQ) dan Spiritual Quotient (SQ) serta mengaitkannya dengan metode content analisis. (2) Mengkaji dan menganalisis Emotional Spiritual Quotient (ESQ) yang ditanamkan dalam proses pembelajaran Pendidikan Agama Islam Kurikulum 2013. (3) Melakukan analisis terhadap konsep pembelajaran berbasis Emotional Spiritual Quotient (ESQ) dan penerapannya dalam standar isi kurikulum 2013 yang memuat kompetensi Spiritual dan Sosial. Dari analisis ini akan diketahui implementasi Emotional Spiritual Quotient (ESQ) dalam proses pembelajaran Pendidikan Agama Islam.

\section{Hasil Penelitian dan Pembahasan}

\section{Aspek-aspek ES Q dalam Pembelajaran Pendidikan Agama Islam Kurikulum 2013}

Kurikulum 2013 adalah kurikulum yang sarat dengan pendidikan karakter. Mindset ini yang disadari sejak awal sebelum memahami teknis 
pelaksanaan Kurikulum 2013. Lahirnya konsep KI (Kompetensi Inti) diawali dari pengelompokan kompetensi pokok atas sikap, pengetahuan dan keterampilan. Awalnya hanya satu rumusan, namun setelah didalami, maka akan muncul sikap spiritual dan sikap sosial.

Tabel. Kompetensi Inti

\begin{tabular}{|c|c|c|}
\hline Tingkat SD/MI & Tingkat SMP/MTS & Tingkat SMA/MA \\
\hline $\begin{array}{l}\text { 1. Menerima, } \\
\text { menjalankan, dan } \\
\text { menghargai ajaran } \\
\text { agama yang dianutnya }\end{array}$ & $\begin{array}{l}\text { 1. Menghargai dan } \\
\text { menghayati ajaran agama } \\
\text { yang dianutnya. }\end{array}$ & $\begin{array}{l}\text { 1. Menghayati dan } \\
\text { mengamalkan ajaran agama } \\
\text { yang dianutnya. }\end{array}$ \\
\hline $\begin{array}{l}\text { 2. Menunjukkan } \\
\text { perilaku jujur, disiplin, } \\
\text { tanggung jawab, } \\
\text { santun, peduli, dan } \\
\text { percaya diri dalam } \\
\text { berinteraksi dengan } \\
\text { keluarga, teman, guru, } \\
\text { dan tetangganya. }\end{array}$ & $\begin{array}{l}\text { 2.Menghargai dan } \\
\text { menghayati perilaku jujur, } \\
\text { disiplin, tanggungjawab, } \\
\text { peduli (toleransi, gotong } \\
\text { royong), santun, percaya } \\
\text { diri, dalam berinteraksi } \\
\text { secara efektif dengan } \\
\text { lingkungan sosial dan } \\
\text { alam dalam jangkauan } \\
\text { pergaulan dan } \\
\text { keberadaannya. }\end{array}$ & $\begin{array}{l}\text { 2. Menghayati dan } \\
\text { mengamalkan perilaku jujur, } \\
\text { disiplin, tanggungjawab, } \\
\text { peduli (gotong royong, } \\
\text { kerjasama, toleran, damai), } \\
\text { santun, responsif dan pro- } \\
\text { aktif dan menunjukkan sikap } \\
\text { sebagai bagian dari solusi atas } \\
\text { berbagai permasalahan dalam } \\
\text { berinteraksi secara efektif } \\
\text { dengan lingkungan sosial dan } \\
\text { alam serta dalam } \\
\text { menempatkan diri sebagai } \\
\text { cerminan bangsa dalam } \\
\text { pergaulan dunia. }\end{array}$ \\
\hline
\end{tabular}


3. Memahami

pengetahuan faktual dengan cara mengamati

dan menanya

berdasarkan rasa ingin

tahu tentang dirinya,

makhluk ciptaan

Tuhan dan

benda-benda yang

dijumpainya di rumah,

di sekolah dan tempat

bermain. kegiatannya, dan
3. Memahami

pengetahuan (faktual,

konseptual, dan

prosedural) berdasarkan

rasa ingin tahunya tentang

ilmu pengetahuan,

teknologi, seni, budaya

terkait fenomena dan

kejadian tampak mata.
3. Memahami, menerapkan, menganalisis pengetahuan faktual, konseptual, prosedural berdasarkan rasa ingin tahunya tentang ilmu pengetahuan, teknologi, seni, budaya, dan humaniora dengan wawasan kemanusiaan, kebangsaan, kenegaraan, dan peradaban terkait penyebab fenomena dan kejadian, serta menerapkan pengetahuan prosedural pada bidang kajian yang spesifik sesuai dengan bakat dan minatnya untuk memecahkan masalah

\section{Menyajikan} pengetahuan faktual dalam bahasa yang jelas, sistematis dan logis, dalam karya yang estetis, dalam gerakan yang mencerminkan anak sehat, dan dalam tindakan yang mencerminkan perilaku anak beriman dan berakhlak mulia.

4.Mencoba, mengolah,
dan menyaji dalam ranah
konkret (menggunakan,
mengurai, merangkai,
memodifikasi, dan
membuat) dan ranah
abstrak (menulis,
membaca, menghitung,
menggambar, dan
mengarang) sesuai dengan
yang dipelajari di sekolah
dan sumber lain yang
sama dalam sudut
pandang/teori.

4. Mengolah, menalar, dan menyaji dalam ranah konkret dan ranah abstrak terkait dengan pengembangan dari yang dipelajarinya di sekolah secara mandiri, dan mampu menggunakan metode sesuai kaidah keilmuan.

Sumber: Lampiran KMA 165 tahun 2014 Revisi 2015

Dari uraian di atas, aspek-aspek Emotional Spiritual Quotient (EQ) yang diintegrasikan dalam pembelajaran Pendidikan Agama Islam Kurikulum 2013 meliputi: kesadaran diri, motivasi diri, kecakapan sosial, hanif, dan tauhidi. Dalam KI-3 aspek Kesadaran diri (consciousness) merupakan alternatif untuk memaksimalkan pembelajaran pada peserta didik, karena kesadaran merupakan modal penting bagi peserta didik dalam memperoleh pengetahuan dan pendidikan. Kesadaran dimulai dengan pengetahuan dasar atau beberapa jenis 
kemampuan yang belum sempurna untuk mengetahui atau menyadari apa yang terjadi. Kesadaran merupakan energi pokok yang luar biasa yang terdapat pada pikiran yang berpengalaman secara sadar.

Motivasi diri masuk dalam KI-3, konsep ESQ terwujud dalam aspek motivasi diri secara prosedural di dalam kegiatan belajar diperlukan tahapantahapan tertentu dalam memahami, menerapkan, menganalisis pengetahuan faktual dibutuhkan rasa ingin tau. Karena dengan adanya rasa ingin akan muncul motivasi diri (self motivation) untuk menerapkan pengetahuan prosedural pada bidang kajian yang spesifik sesuai dengan bakat dan minatnya untuk memecahkan masalah.

Aspek sosial muncul pada KI-2. Karena Kurikulum 2013 merupakan kurikulum yang berbasis karakter dan kompetensi, maka Kurikulum 2013 tidak hanya menekankan kepada pengusaan kompetensi siswa, melainkan juga pembentukkan karakter sosial. Sesuai dengan kompetensi inti (KI) yang telah ditentukan oleh Kemendikbud, KI 1 dan KI 2 berkaitan dengan tujuan pembentukkan karakter siswa sedangkan KI 3 dan KI 4 berkaitan dengan penguasaan kompetensi siswa.

Aspek hanif terkandung dalam KI-1 yang didalamnya terdapat aspek sikap untuk menerima, menjalankan, menghargai, menghayati dan mengamalkan ajaran agama yang dianutnya adalah wujud dari kemampuan diri peserta didik untuk memberi makna ibadah terhadap setiap pembelajaran untuk menuju manusia yang seutuhnya (hanif), dan memiliki pola pemikiran tauhidi (integralistik), serta berprinsip "hanya karena Allah". Karena dasar dari diciptakannya manusia juga hanya untuk menyembah kepada Allah Swt. Berkaitan dengan ESQ ini Al Qur'an menegaskan bahwa sifat dasar (fitrah) manusia adalah mempunyai kecenderungan kepada kebaikan (hanif). Fitrah manusia yang hanif (cenderung kepada kebenaran) ini menujukan adanya kehadiran Tuhan (Jejak Tuhan) dalam diri manusia.

Pada dasarnya setiap tindakan dan perilaku manusia dipengaruhi oleh fitrah kemanusianya. Dengan bertindak sesuai dengan fitrah maka seseorang akan memiliki kejujuran, kebikjasanaan (wisdom), visioner, tabah (berani mengambil resiko), ahlak yang terpuji (ahlaqul karimah), memiliki prinsip (iman) yang teguh, bertanggung jawab dan mampu memberikan hasil yang berupa amal saleh sehingga hidupnya akan penuh nilai dan makna. Dengan kata lain, orang yang memiliki kesadaran fitrah adalah orang yang cerdas secara spiritual.

Di dalam Islam, penanaman sikap dalam pembelajaran berhubungan dengan kecakapan emosi dan spiritual seperti konsistensi (istiqamah), kerendahan hati (tawadlu), berusaha dan berserah diri (tawakal), ketulusan/sincerety (keikhlasan), totalitas (kaffah), keseimbangan (tawazun), 
Integritas dan penyempurnaan (ihsan) kesemuanya itu dinamakan Akhlakul Karimah. Artinya penguatan ESQ dalam pembelajaran adalah upaya untuk menanamkan nilai-nilai akhlakul karimah yang sejalan dengan konsep pendidikan agama Islam. Dengan diteguhkannya nilai-nilai akhlakul karimah akan terbentuk tiga unsur penting dalam agama Islam yakni, Iman, Islam, dan Ihsan sebagai kesatuan yang utuh.

Aspek Taubidi muncul dalam KI-1. Tauhid merupakan esensi dari keimanan kepada Allah swt. Karena itu tauhid lillah memiliki kedudukan dan keutamaan yang sangat kuat. Ranah yang terkandung dalam KI-1 adalah menerima, menghargai, menghayati dan menjalankan ajaran agama yang dianutnya. Artinya dalam KI-1 ini, peserta didik harus memahami inti dari ajaran Islam yaitu Tauhid. Dikandung maksud bahwa tingkatan dasar aspek spiritual yang ditanamkan terhadap siswa pada jenjang pendidikan dasar adalah menerima, menjalankan dan menghargai terhadap ajaran tauhid. Pada tahapan ini, peserta didik masih dalam tahapan mengenal. Setelah itu menjalankan, karena dalam aspek ini, peserta didik pada usia dini perlu untuk membiasakan diri dengan kegiatan spiritual. Setelah tahapan menerima dan menjalankan, peserta didik diajak untuk menghargai. Kemudian tahapan penting berikutnya adalah menghayati dan mengamalkan.

Tauhid merupakan inti dan dasar dari seluruh tata nilai dan norma Islam, sehingga oleh karenanya Islam dikenal sebagai agama tauhid yaitu agama yang mengesakan Allah Swt. Seorang muslim meyakini bahwa tauhid adalah dasar Islam yang paling agung dan hakikat Islam yang paling besar, dan merupakan salah satu syarat diterimanya amal perbuatan disamping harus sesuai dengan tuntunan Rasulullah Saw.

Tauhid merupakan kewajiban utama dan pertama yang diperintahkan Allah Swt. kepada setiap hamba-Nya. Namun, sangat disayangkan kebanyakan kaum muslimin pada zaman sekarang ini tidak mengerti hakekat dan kedudukan tauhid. Padahal tauhid inilah yang merupakan dasar agama kita yang mulia ini. Oleh karena itu sangatlah urgen bagi kita umat Islam untuk mengerti hakekat dan kedudukan tauhid. Hakekat tauhid adalah mengesakan Allah Swt.

Kalimat tauhid merupakan esensi dari ajaran Islam. Ia adalah fondasi dari seluruh bangunan Islam. Pandangan hidup tauhid bukan saja mengesakan Allah Swt., melainkan juga meliputi keyakinan kesatuan penciptaan (unity of creation), kesatuan kemanusiaan (unity of mankind), kesatuan tuntunan hidup (unity of the guidance of life), dan kesatuan tujuan hidup (unity of the purpose of life); yang semuanya merupakan derivasi dari kesatuan ketuhanan (unity of Godhead) 
Dengan pendidikan tauhid, manusia akan menjadi manusia hamba bukan manusia yang dehumanis kemudian timbul rasa saling mengasihi, tolong menolong, memberikan hartanya yang lebih kepada mereka yang membutuhkan selalu waspada terhadap tipu daya dunia dan manusia zalim, dapat belaku sederhana (zuhud) dan hati yang wara serta sebagainya. Dengan demikian pendidikan tauhid mempunyai makna yang dapat dipahami sebagai upaya untuk menampakkan atau mengaktualisasikan potensi laten yang dimiliki oleh setiap manusia (fitrah). Salah satu fitrah manusia adalah fitrah beragama maka dari itu pendidikan tauhid lebih diarahkan pada pengembangan fitrah keberagamaan seseorang sebagai manusia tauhid.

Dengan kata lain pendidikan tauhid adalah usaha mengubah tingkah laku manusia berdasarkan ajaran tauhid dalam kehidupan melalui bimbingan, pengajaran dan pelatihan dengan dilandasi oleh keyakinan kepada Allah Swt. semata.

Dari pemahaman aspak-aspek di atas, kompetensi yang bersifat generik mencakup 3 (tiga) ranah yakni sikap, pengetahuan dan keterampilan. Ranah sikap dipilah menjadi sikap spiritual dan sikap sosial. Pemilahan ini diperlukan untuk menekankan pentingnya keseimbangan fungsi sebagai manusia seutuhnya yang mencakup aspek spiritual dan aspek sosial sebagaimana diamanatkan dalam tujuan pendidikan nasional. Dengan demikian, Kompetensi yang bersifat generik terdiri atas 4 (empat) dimensi yang merepresentasikan sikap spiritual, sikap sosial, pengetahuan, dan keterampilan, yang selanjutnya disebut Kompetensi Inti (KI).

Penanaman Emotional Spiritual Quotient (SQ) dalam pembelajaran PAI akan berimplikasi terhadap (1) Kemampuan mengenal Tuhan; (2) Kemampuan mengenal diri (kesadaran diri); (3) Kemampuan mengelola emosi (penguasaan diri); (4) Kemampuan memotivasi diri; (5) Kemampuan mengendalikan diri; (6) Kemampuan melihat kesatuan dalam keanekaragaman; (7) Kemampuan mengelola dan bertahan dalam kesulitan dan penderitaan; (8) Kemampuan memaknai setiap sisi kehidupan; (9) Kemampuan mengelola dan bertahan dalam kesulitan dan penderitaan; (10) Kemampuan memahami kehidupan ukhrawi.

Untuk mewujudkan aspek-aspek EQ dan SQ dalam pembelajaran PAI Kurikulum 2013, maka dilakukan penilaian sikap dalam bentuk observasi, penilaian diri, penilaian antar peserta didik, jurnal. Dengan pembelajaran saintifik peserta didik menjadi lebih aktif dalam menkonstruksi konsep, hukum atau prinsip melalui tahapan-tahapan mengamati, merumuskan masalah, mengajukan atau merumuskan hipotesis, mengumpulkan data dengan berbagai teknik, menganalisis data, menarik kesimpulan dan mengkomunikasikan konsep, hukum atau prinsip yang ditemukan. Adapun untuk menilai 
kompetensi peserta didik pada ranah kognitif guru menyiapkan penilaian yang meliputi: (1) Instrumen tes tulis. (2) Instrumen tes lisan. (3) Instrumen penugasan berupa pekerjaan rumah dan/atau projek yang dikerjakan secara individu atau kelompok sesuai dengan karakteristik tugas yang akan dikerjakan peserta didik.

Untuk mengetahui kompetensi keterampilan, seorang pendidik harus menilai kompetensi keterampilan melalui penilaian kinerja, yaitu penilaian yang menuntut peserta didik mendemonstrasikan suatu kompetensi tertentu dengan menggunakan tes praktik, projek, produk dan penilaian portofolio. Instrumen yang digunakan berupa daftar cek atau skala penilaian (rating scale) yang dilengkapi rubrik.

Kecerdasan emosional yang ditandai dengan kepribadian seperti rasa empati, kasih sayang, saling menghormati, menghargai, jujur, pemaaf, sabar, atau mengendalikan diri, merupakan tahap awal menuju kecerdasan yang lebih tinggi yakni kecerdasan spiritual. Ketika makhluk hidup menghadapi rangsangan, baik dari dalam maupun dari luar, maka dia menjadi gelisah dan risau dan merasa tidak enak/konflik. Dalam hal ini struktur kejiwaannya berada dalam goyangan dan tidak seimbang. Dalam hal ini manusia sebagai wadah kekuatan berusaha menurunkan ketegangan dan menjaga keseimbangan dengan cara menurunkan atau menghilangkan rangsangan-rangsangan.

Kejujuran menempati urutan teratas sifat yang harus dimiliki seseorang. Kejujuran atau integritas bukan saja konsep mulia, melainkan juga alat untuk mencapai sukses pribadi, perusahaan, lembaga atau organisasi. Pengembangan kurikulum pendidikan dalam membentuk karakter, mental dan moral generasi muda perlu tanamkan prinsip-prinsip emosional dan spiritual di antaranya: (1) Membangun prinsip bintang sebagai pegangan hidup; (2) Memiliki prinsip Malaikat sehingga akan selalu dipercaya oleh manusia/orang lain; (3) Prinsip kepemimpinan, yang nantinya mampu membimbing menjadi seorang pemimpin yang berpengaruh; (4) Prinsip pembelajaran, yang akan mendorong kepada suatu kemajuan; (5) Prinsip masa depan, sehingga akan selalu memiliki visi; (6) Prinsip tertib, sehingga tercipta sistem dalam satu kesatuan tauhid, atau prinsip Esa di dalam berfikir.

Untuk memenuhi pengembangan kerangka berpikir yang sesuai dengan kebutuhan Pendidikan Agama Islam, maka kurikulum 2013 menanamkan pola pikir sebagai berikut; 1) Pola pembelajaran yang berpusat pada guru menjadi pembelajaran berpusat pada peserta didik. Peserta didik harus memiliki pilihan-pilihan terhadap materi yang dipelajari untuk memiliki kompetensi yang sama; 2) Pola pembelajaran satu arah (interaksi guru-peserta didik) menjadi pembelajaran interaktif (interaktif guru-peserta didik-masyarakatlingkungan alam, sumber/media lainnya); 3) Pola pembelajaran terisolasi 
menjadi pembelajaran secara jejaring (peserta didik dapat menimba ilmu dari siapa saja dan dari mana saja yang dapat dihubungi serta diperoleh melalui internet); 4) Pola pembelajaran pasif menjadi pembelajaran aktif-mencari (pembelajaran peserta didik aktif mencari semakin diperkuat dengan model pembelajaran pendekatan sains); 5) Pola belajar sendiri menjadi belajar kelompok (berbasis tim); 6) Pola pembelajaran alat tunggal menjadi pembelajaran berbasis alat multimedia; 7) Pola pembelajaran berbasis massal menjadi kebutuhan pelanggan (users) dengan memperkuat pengembangan potensi khusus yang dimiliki setiap peserta didik; 8) Pola pembelajaran ilmu pengetahuan tunggal (monodiscipline) menjadi pembelajaran ilmu pengetahuan jamak (multidiscipline); 9) Pola pembelajaran pasif menjadi pembelajaran kritis.

Di antara salah satu aspek sikap yang sangat relevan diimplementasikan dalam pendidikan sekarang ini adalah sikap jujur. Kejujuran yang diterapkan dalam sistem evaluasi pendidikan menunjukkan saat hasil ujian nasional (UN) tahun 2017 disampaikan secara umum. Pada UN tahun ini, Kemendikbud mencatat adanya peningkatan indeks integritas, baik di sekolah yang menerapkan UN berbasis komputer (UNBK) maupun sekolah yang menjalankan UN berbasis kertas dan pensil (UNKP). Faktanya sekolah/madrasah yang tahun lalu menerapkan UNBK dan memiliki indeks integritas tinggi, tahun ini indeks integritasnya meningkat sebesar 3,39 poin. Hasil tersebut menjadi indikator bahwa UNBK adalah moda pengadministrasian tes yang lebih menjamin integritas pelaksanaan dan memberi gambaran capaian yang sesungguhnya.

Kesimpulan

Berdasarkan penjelasan di atas, maka ada dua hal yang menjadi tujuan penelitian ini yaitu aspek-aspek Emotional Spiritual Quotient (ESQ) dalam Pembelajaran Pendidikan Agama Islam Kurikulum 2013 dan relevansinya dalam dunia pendidikan masa kini. Berikut kesimpulan dari penelitian ini; Pertama, aspek-aspek Emotional Spiritual Quotient (ESQ) dalam pembelajaran Pendidikan Agama Islam Kurikulum 2013 meliputi keimanan dan ketakwaan, akhlak mulia, jujur, disiplin, tanggungjawab, peduli (gotong royong, kerjasama, toleran, damai), santun, responsif dan pro-aktif percaya diri dalam berinteraksi dengan keluarga, teman, guru, lingkungan dan masyarakat. Namun diantara beberapa aspek ESQ yang sangat signifikan pengaruhnya dalam pembelajaran dan penilaian adalah sikap jujur. Kejujuran menjadi penentu integritas pendidikan sekaligus menjadi penjamin mutu pendidikan. Kecerdasan emosional juga mengajarkan tentang integritas kejujuran komitmen, visi, kreatifitas, ketahanan mental kebijaksanaan dan penguasaan. 
EQ merupakan kecerdasan yang memberikan kesadaran mengenai perasaan milik sendiri dan milik orang lain, yang memberikan rasa empati, cinta, motivasi dan kemampuan untuk menanggapi kesedihan dan kegembiraan secara tepat. Kedua, relevansi Emotional Spiritual Quotient (ESQ) dalam Pembelajaran Pendidikan Agama Islam Kurikulum 2013 dengan fenomena pendidikan saat ini. Bahwa dalam dunia pendidikan masa kini, yang lebih bercorak modern dan sekuler kadang-kadang berakibat ke arah hilangnya kualitas manusiawi (spiritual dan moral). Oleh karena itu perlu diterapkan suatu sistem pembelajaran yang lebih memprioritaskan keseimbangan antara kecerdasan intelektual, emosional dan spiritual. Kemampuan menanamkan nilai-nilai akhlakul karimah akan terbentuk tiga unsur penting dalam agama Islam yakni, iman, Islam, dan ihsan sebagai kesatuan yang utuh.

\section{DAFTAR PUSTAKA}

Abdullah, R. (2002). Aktualiasi Konsep Pendidikan Islam (Rekontruksi Pemikiran Dalam Tinjauan Filsafat Pendidikan Islam). Yogyakarta: UII Press.

Agustian, A. G. (2007). Rahasia Sukses Membangun Kecerdasan Emosi dan Spiritual ESQ: Emotional Spiritual Quotient Berdasarkan 6 rukun Iman dan 5 rukun Islam. Jakarta: Arga.

Al-Attas, M. N. (1984). Konsep Pendidikan dalam Islam: Suatu Rangka Pikir Pembinaan Filsafat Pendidikan Islam. Bandung: Mizan.

Ali, H. (1993). Filasat Pendidikan. Yogyakarta: Kota Kembang.

Budiman, M. N. (2016). Ideologi Pendidikan Qur'ani: Gagasan dan Tawaran. Banda Aceh: Bandar Publishing.

Daryanto, \& Amirono. (2016). Evaluasi \& Penilaian Pembelajaran Kurikulum 2013. Yogyakarta: Penerbit Gava Media.

Goleman, D. (2007). Emotional Intelligence, terj. T. Hermaya, Kecerdasan Emosional, Mengapa EQ Lebih Penting Daripada IQ. Jakarta: Gramedia Pustaka Utama.

Hasyim, F. (2015). Kurikulum Pendidikan Agama Islam (Filosofi Pengembangan Kurikulum Transformatif Antara KTSP dan Kurikulum 2013. Malang: Setara Press.

Herawati, W. L., \& Mulyanratna, M. (2014). Studi Korelasi Antara Kecerdasan Emosional Spiritual (ESQ) dan Hasil Belajar Fisika Siswa Madrasah Aliyah Swasta (MAS) di Wilayah Kecamatan Dukun Kabupaten Gresik. Inovasi Pendidikan Fisika, 3(2), 161-166.

Hidayat, K., \& dkk. (2002). Menyinari Relung-Relung Ruhani, Mengembangkan 
EQ dan SQ Cara Sufi. Bandung: Hikmah.

Moleong, J. L. (2010). Metodologi Penelitian Kualitatif. Bandung: PT. Remaja Rosdakarya.

Mubarok, A. (2001). Psikologi Qur'ani. Jakarta: Pustaka Firdaus.

Mudzakir, J., \& Mujib, A. (2001). Nuansa-Nuansa Psikologi Islam. Jakarta: Raja Grafindo Persada.

Muhaemin. (2004). Arah Baru Pengembangan Pendidikan Islam. Bandung: Nuansa.

O`neil, W. F. (2002). Ideologi-Ideologi Pendidikan. Yogyakarta: Pustaka Pelajar. Pasiak, T. (2002). Revolusi IQ, EQ, SQ; Antara Nerurosains dan Al Qur'an. Bandung: Mizan.

Pawito. (2008). Penelitian Komunikasi Kualitatif. Yogyakarta: PT. LKiS Pelangi Aksara.

Prawira, P. A. (2012). Psikologi Pendidikan Dalam Persepektif Baru. Yogyakarta: Ar-Ruzz Media.

Puluhulawa, C. W. (2013). Kecerdasan Emosional dan Kecerdasan Spiritual Meningkatkan Kompetensi Sosial Guru. Makara Human Behavior Studies in Asia, 17(2), 139-147. https://doi.org/10.7454/mssh.v17i2.2957

Rusman. (2009). Manajemen Kurikulum. Jakarta: Raja Grapindo Persada.

Sukardi. (2005). Metodelogi Penelitian Pendidikan, Kompetensi dan Prakteknya. Jakarta: Bumi Aksara.

Supriadi, D. (1997). Dari IQ dan CQ ke EQ, Persfektif Baru Pendidikan. Bandung: Jurusan PPB FIP IKIP Bandung.

Suryabrata, S. (2014). Metodologi Penelitian (Cet. 25). Jakarta: Rajawali Pers.

Tasmara, T. (2001). Kecerdasan Ruhaniah. Jakarta: Gema Insani Press.

Yani, A. (2014). Mindset Kurikulum 2013 (Cet. 2). Bandung: Alfabeta.

Zed, M. (2008). Metode Penelitian Kepustakaan. Jakarta: Yayasan Obor Indonesia.

Zohar, D. (2002). Spiritual Intelligence The Ultimate Intelligence, terj. Rahmani Astuti, et.all. Bandung: Mizan.

Zohar, D., \& Marshall, I. (2007). SQ: Memanfaatkan Kecerdasan Spiritual Dalam Berfikir Integralistik dan Holistik Untuk Memaknai Kehidupan. Bandung: Mizan. 
